\author{
Artículo científico \\ (Original paper)
}

\title{
ACCESSIBILITY DO NOT EXPLAIN ABUNDANCE OF MEDIUM AND LARGE-SIZED MAMMALS IN TERRA DO MEIO, ALTAMIRA, PARÁ, BRAZIL
}

\author{
ROBERTO PORTELla DE ANDRADE ${ }^{1}$, RODOLFO SALM ${ }^{2}$, ISADORA FRANÇA², EMIL JOSÉ HERNANDÉZ \\ RUZ ${ }^{1 *}$ \\ ${ }^{1}$ Universidade Federal do Pará, Programa de Pós-graduação em Biodiversidade e Conservação, Rua Coronel José Porfírio, 2515 , \\ Esplanada do Xingu, 68.372-040, Altamira, PA, Brazil. <rtportella@ hotmail.com>; <emilhjh@yahoo.com> \\ ${ }^{2}$ Universidade Federal do Pará, Faculdade de Ciências Biológicas, Rua Coronel José Porfírio, 2515, Esplanada do Xingu, 68.372 - \\ 040, Altamira, PA, Brazil.<rodolfosalm@ufpa.br>; <isa_bio@yahoo.com.br> \\ *Autor de correspondencia: <emilhjh@yahoo.com>
}

Recibido: 21/05/2018; aceptado: 03/05/2019; publicado en línea: 15/05/2019

Editor responsable: Vinicio Sosa

Andrade, R. P., Salm, R., França, I., Hernandéz-Ruz, E. J. (2019) Accessibility do not explain abundance of medium and large-sized mammals in Terra Do Meio, Altamira, Pará, Brazil. Acta Zoológica Mexicana (Nueva Serie), 35, 1-10. https://doi.org/10.21829/azm.2019.3501219

\begin{abstract}
The aim of this study was to evaluate the effects of accessibility on hunting pressure by considering the mammal abundance and biomass of two protected areas belonging to different conservation categories -indigenous land and Ecological Station- in the Xingu River basin, eastern Amazon. For doing so, we used linear transection methods (total effort $240 \mathrm{~km}$, in four tracks), camera traps (487 days) and complementary records. We also developed an accessibility coefficient based on the distance between navigable rivers and roads, and the center point of the sampled trails. We used the Simple linear regression test to analyze the effects of this accessibility on the biomass of the sighted species, gathering them in orders. We found 34 species belonging to seven families and six orders. We found no relation between mammal biomass and our accessibility index, which suggests that hunting pressure affects even the most distant studied areas.
\end{abstract}

Key words: Hunting; environmental disturbance; Eastern Amazon; conservation; mastofauna

RESUMO. Nosso objetivo foi analisar os efeitos da acessibilidade sobre a pressão de caça refletida na abundância e biomassa de mamíferos em duas áreas protegidas de diferentes categorias de conservação. Terra indígena e Estação Ecológica, na bacia do rio Xingu, no leste da Amazônia. Para tal, usamos os métodos de transição linear (esforço de $240 \mathrm{~km}$ ), armadilhas fotográficas (487 dias) e registros complementares. Adicionalmente, desenvolvemos um coeficiente de acessibilidade com base na distância dos rios e estradas navegáveis para o ponto central das trilhas percorridas. Utilizamos regressão linear simples para analisar os efeitos da acessibilidade sobre a biomassa das espécies avistadas (agrupadas em ordens). Encontramos 34 espécies pertencentes a 07 famílias. Não encontramos relação entre a biomassa de mamíferos e nosso índice de acessibilidade, sugerindo que a pressão de caça afeta a área estudada a uma maior distância. 
Andrade et al.: Accessibility do not explain abundance of medium and large-

sized mammals

Palavras chave: Caça; distúrbios ambientais; reserva ambiental; Amazônia oriental; conservação; mastofauna

\section{INTRODUCTION}

Variations in hunting pressure explain differences in medium and large-sized vertebrate densities in tropical rain forests worldwide (Peres, 2000; Levi et al., 2009; De Andrade Melo et al., 2015; Constantino, 2016). It is generally considered that such variation is intrinsically connected to the accessibility to hunting areas, which depends on factors such as the distance to rivers, roads and human settlements which influence the walking distance covered by hunters to the hunting area (De Souza-Mazurek et al., 2000; Peres \& Lake, 2003). Accessibility also negatively affects refuge areas, which are sources of wildlife, impoverishing local biological communities (Espinosa et al., 2014; Fragoso et al., 2000; Harrison, 2011).

In the Tropics, road expansion is associated with increases in hunting pressure as road networks expand and the area of forest accessible to hunters increases (Laurance et al., 2009, Espinosa et al., 2014). Studies of the impact of roads and hunting on Tropical Rainforest Mammals found different responses, for example, in Congo Basin, hunting had the greatest impact on Cetartyodactyla and a lower impact on Carnivores. Monkey species showed little response to roads or hunting, whereas some rodents increased in abundance (Laurance et al., 2006). In the Neotropics, the first to become rare or extinct from impacted areas are the large-bodied, terrestrial mammals such as the white-lipped peccary, jaguar, giant ant-eater, tapir, puma and collared peccary (Azevedo \& Conforti, 2008; Naranjo \& Bodmer, 2007; Melo et al., 2015, Meyer et al., 2015, Luna et al., 2017). The differentiated responses of the mammals to hunting depend on biological factors such as: their higher energetic demands, larger home ranges, slower reproductive rates, and densities (Peres, 2000; Brown \& Brown, 1992) and the cultural factors of the hunters, such as their ethnic origin and dietary preferences (Peres, 2000), taboos and hunting practices (Levi et al., 2009, Alvard, 1993).

Hunting by subsistence hunters are concentrated around settlements and near the margins of rivers and roads (Sirén et al., 2006; Levi et al., 2009; Espinosa et al., 2014), as described by central place foragers. On the other hand, there is a pattern related to depletion near settlements that tend to have lower capture per unit of effort than remote hunting sites (Fragoso, 1998).

The aim of this study was to investigate the effects of accessibility on the abundance of mammals in two protected areas in the Xingu River Basin, in the State of Pará, Brazil.

\section{MATERIALS AND METHODS}

Study area. This study was developed in two adjacent protected areas in the Xingu River basin eastern Amazon (Fig. 1): The Terra do Meio Ecological Station (TMES) area is located in the South-Central region of the State of Pará, covering an area of 3,373,110 ha. The TMES is surrounded by other protected areas (Velásquez, 2007). Nowadays, 15 families are authorized to live in this area, performing traditional activities such as subsistence fishing and extractivism (ICMBio, 2015). It is composed of dense evergreen forest (18\%) and open forest (82\%) (MMA, 2007).

The Cachoeira Seca Indigenous Land (CSIL) was officially created on 2008 and is located in the South-Central region of Pará, covering an area of 734,027 ha. It is inhabited by 87 Native American people from the Arara ethnicity and, illegally, by more than one thousand settlers, making each a region of interethnic conflict (Doblas, 2015). The CSIL is also composed of dense evergreen forest (32\%) and open forest (68\%) (ISA, 2016). 
Sampling. These trails were explored with an average speed between 1.2 and $2 \mathrm{~km} / \mathrm{h}$, registering the presence of mammals from the target group (Burnham et al., 1980; Peres \& Cunha, 2011). The transect sections were explored by a researcher and an auxiliary between 6:30 am and $6 \mathrm{pm}$ from May 2015 to June 2016. To each animal or group of animals visualized during the census, the following information was registered in field sheets: species, group size, perpendicular distance, time and location in the transect, among other data. In cases of climate adversities such as little visibility, rain or wind, the census could be temporarily interrupted and restarted in conditions which do not compromise the sighting (Peres \& Cunha, 2011). In the data collection, a special effort was made to fulfill the four methodological premises provided by Burnham et al. (1980), assuring the reliability of the results.

The traps were installed perpendicular to the line transect, in alternative trails and along the banks of the Novo and Iriri Rivers during fieldwork. The spots were selected by an experienced fieldwork auxiliary. The 14 camera traps (nighthawk $35 \mathrm{~mm}$ and digital trap camera Canon® PowerShot A470) were individually set on trees at a height of 30 to 40 centimeters from the ground and with a minimum distance of 500 meters between them. The traps available for the present study were set to work throughout the whole fieldwork time, with total effort of the 487 camera days.

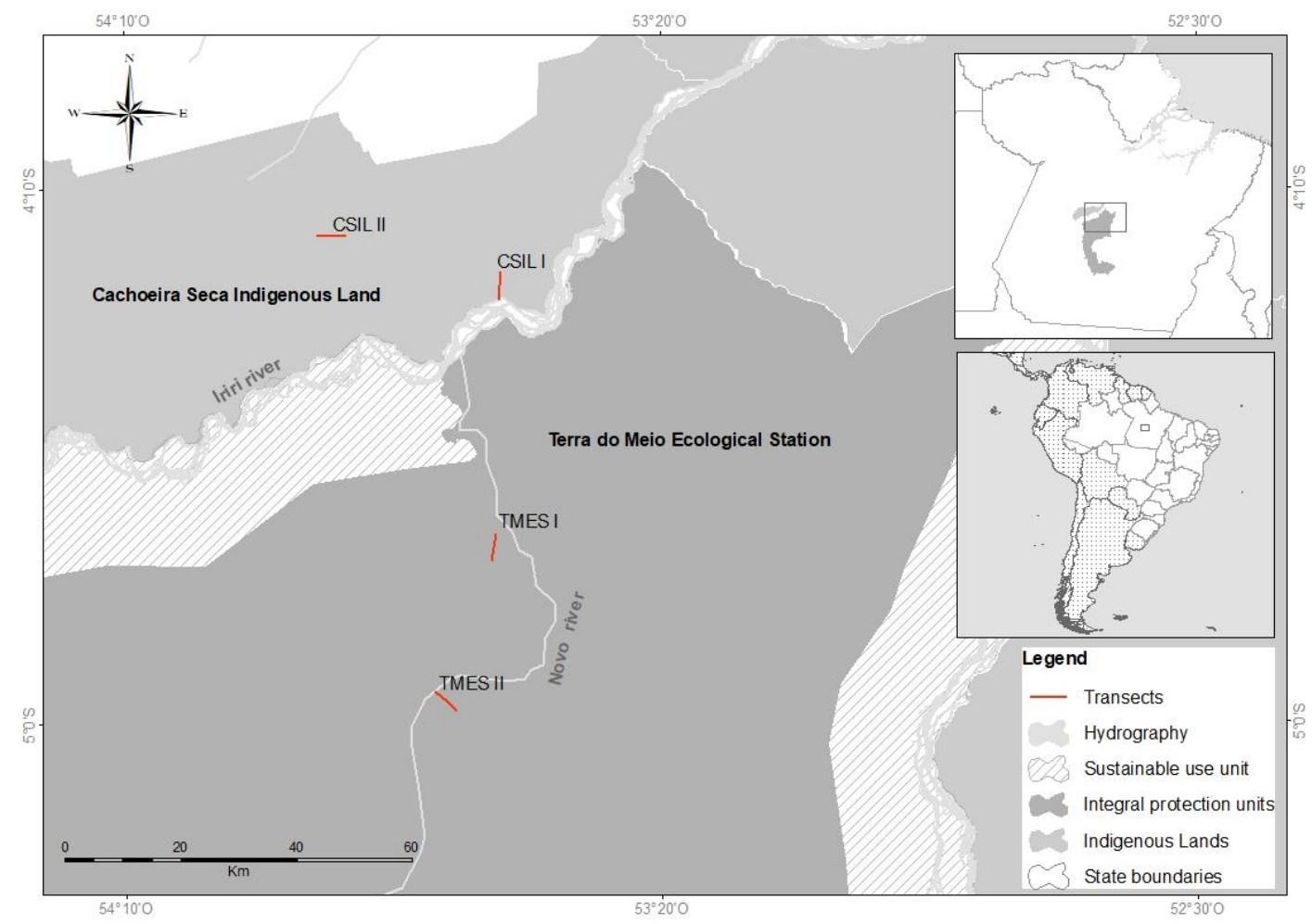

Figure 1. Conservation units and Indigenous Land constituting the Terra do Meio mosaic.

Another method used to make the mammal species list of this study was based on the occurrence signs of the target species (footprints, feces, vocalizations, anatomical parts and occasional encounters) during the activities in the field (installation and monitoring of the transects and trap cameras; Fragoso $e t$ al., 2016).

The studies in the protected areas were performed under the authorizations $\mathrm{n}^{\circ} 48195-2$ MMA/ICMBio and $n^{\circ}$ 022/AAEO/PRES/2016 FUNAI. 
Andrade et al.: Accessibility do not explain abundance of medium and large-

sized mammals

The taxonomic nomenclature of the 52 expected species in these areas of study followed the instructions proposed by Wilson \& Reeder (2005) and by Reis et al. (2010). Due to the difficulties in determining a reliable taxonomic identification, some families of medium-sized species, from the order Rodentia, such as Muridae and Echimyidae, as well as from the order Didelphimorphia, Didelphidae, were omitted. The inclusion of small species, such as Guerlinguetus aestuans and Mico argentatus, is usual in studies because of the similarity between the registration methods of medium and large species (Santos \& Mendes-Oliveira, 2012; Costa-Pereira et al., 2013; Benchimol \& Peres, 2015).

Data Analysis. The biomass of adult species sighted (biomass $/ 5 \mathrm{~km}$ covered) by area was set by multiplying the number of adults sighted at every $5 \mathrm{~km}$ by its body weight. According to De Andrade Melo et al. (2015), the arithmetic average of mass reported by Eisenberg and Redford (1999), Emmons \& Feer (1997) and Reis et al. (2010) was considered in the body weight.

The accessibility coefficient was established by calculating the average proportions of the distances from navigable rivers and trafficable roads to the central spot of the covered trails (Table 1). We used simple linear regression and the logarithmic transformation in the biomass variable was applied so that the residuals of the model had normal distribution (Zar, 1974) in the R program (R Core Team, 2018).

Table 1. Effort distances from rivers, roads and settlements in analyzed transects.

\begin{tabular}{cccccc}
\hline Transect & $\begin{array}{c}\text { Length } \\
(\mathbf{k m})\end{array}$ & $\begin{array}{c}\text { Effort } \\
(\mathbf{k m})\end{array}$ & $\begin{array}{c}\text { Distance from the } \\
\text { river }(\mathbf{k m})\end{array}$ & $\begin{array}{c}\text { Distance from road } \\
\mathbf{( k m})\end{array}$ & $\begin{array}{c}\text { Distance from the } \\
\text { settlement } \mathbf{( k m})\end{array}$ \\
\hline CSIL I & 5 & 81.75 & 2 & 10 & 8 \\
\hline CSIL II & 5 & 38.25 & 18 & 2 & 23.4 \\
\hline TMES I & 5 & 65 & 32 & 41 & 41 \\
\hline TMES II & 5 & 55 & 54 & 64 & 64 \\
\hline
\end{tabular}

\section{RESULTS}

In this study, we confirmed the presence of 34 of the 52 species of medium and large-size mammals expected to be found in the studied region according to the literature (Reis et al., 2010; Emmons \& Feer, 1997; IUCN, 2016).

The linear transect method registered the presence of 19 species (Table 2); the camera trap, 19 (Table 3); and the complementary register, 29. Most of the records of the species were shared by the three methods; however, the species Chiropotes albinasius and Guerlinguetus aestuans were exclusive to the first method, Procyon cancrivorous to the second, and Lontra longicaudis, Pteronura brasiliensis, Coendou preensilis, Hydrochaeris hydrochaeris and Aotus infulatus to the occurrence signs method.

The linear effect of accessibility on the biomass of orders in the studied areas was not significant ( $\mathrm{F}$ $=0.885 ; \mathrm{p}>0.05 ; \mathrm{df}=46$ ).

\section{DISCUSSION}

We show that facilitation of hunter access to a natural landscape can lead to a development-induced impact on the abundance of mammals and that the effect of hunting affects at distances greater than $10 \mathrm{~km}$ from the transects to the trafficable roads and navigable rivers. In a theoretic study of hunted areas (BenítezLópez et al., 2017), it was found that birds and mammals were depleted within 7 and 40 kilometers from the hunters' access points (roads and settlements). In other studies, it was neither found a significant 
difference in the levels of accessibility, abundance of orders and biomass of adult animals (De Andrade Melo et al., 2015; Antunes et al., 2016). Although the density of residents is 1 inhab $/ \mathrm{km}^{2}$ (Harrison, 2011), it is possible that the whole area is influenced by poachers from Uruará and elsewhere. Traditionally, it is known that humans living in or adjacent to national parks threaten the preservation of some parks and reserves by hunting, building settlements, and other human activities (Pimentel et al., 1992) and, in Terra do Meio, this is not the exception.

Table 2. Orders and species registered by the line transect method in the TMES and CSIL during the period of May 2014 and May 2016.

\begin{tabular}{|c|c|c|c|c|c|c|c|c|}
\hline \multirow[b]{2}{*}{ Taxon } & \multicolumn{2}{|c|}{$\begin{array}{c}\text { TMES I } \\
(65 \mathrm{Km}) \\
\end{array}$} & \multicolumn{2}{|c|}{$\begin{array}{c}\text { TMES II } \\
(55 \mathrm{Km}) \\
\end{array}$} & \multicolumn{2}{|c|}{$\begin{array}{c}\text { CSILI } \\
(81,75 \mathrm{Km}) \\
\end{array}$} & \multicolumn{2}{|c|}{$\begin{array}{c}\text { CSILII } \\
(38,25 \mathrm{Km}) \\
\end{array}$} \\
\hline & Sights & Rate & Sights & Rate & Sights & Rate & Sights & Rate \\
\hline Artiodactyla & 4 & 0.62 & 7 & 1.27 & 7 & 0.86 & 0 & 0 \\
\hline Mazama americana & 1 & 0.15 & 5 & 0.91 & & & 0 & 0 \\
\hline Pecari tajacu & 3 & 0.46 & 1 & 0.18 & 5 & 0.61 & 0 & 0 \\
\hline Tayassu pecari & & & 1 & 0.18 & 2 & 0.24 & 0 & 0 \\
\hline Carnivora & 2 & 0.31 & 3 & 0.55 & 2 & 0.24 & 0 & 0 \\
\hline Eira barbara & 1 & 0.15 & & & 1 & 0.12 & 0 & 0 \\
\hline Leopardus wiedii & 1 & 0.15 & & & & & & \\
\hline Nasua nasua & & & 2 & 0.36 & 1 & 0.12 & 0 & 0 \\
\hline Puma concolor & & & 1 & 0.18 & & & 0 & 0 \\
\hline Perissodactyla & & & 1 & 0.18 & & & 0 & 0 \\
\hline Tapirus terrestris & & & 1 & 0.18 & & & 0 & 0 \\
\hline $\begin{array}{c}\text { Pilosa } \\
\end{array}$ & 1 & 0.15 & 1 & 0.18 & 1 & 0.12 & 1 & 0.26 \\
\hline Bradypus variegatus & & & & & & & 1 & 0.26 \\
\hline Tamandua tetradactyla & 1 & 0.15 & 1 & 0.18 & 1 & 0.12 & & \\
\hline Primates & 36 & 5.54 & 27 & 4.91 & 29 & 3.55 & 30 & 7.84 \\
\hline Alouatta discolor & & & & & 1 & 0.12 & & \\
\hline Ateles marginatus & 2 & 0.31 & 2 & 0.36 & 1 & 0.12 & 1 & 0.26 \\
\hline Callicebus moloch & 12 & 1.85 & 6 & 1.09 & 7 & 0.86 & 7 & 1.83 \\
\hline Chiropotes albinasus & & & & & 1 & 0.12 & 1 & 0.26 \\
\hline Mico argentatus & & & & & 2 & 0.24 & 4 & 1.05 \\
\hline Sapajus apella & 16 & 2.46 & 15 & 2.73 & 11 & 1.35 & 15 & 3.92 \\
\hline Saimiri sciureus & 6 & 0.92 & 4 & 0.73 & 6 & 0.73 & 2 & 0.52 \\
\hline Rodentia & 25 & 3.85 & 48 & 8.73 & 27 & 3.3 & 17 & 4.44 \\
\hline Dasyprocta leporina & 18 & 2.77 & 30 & 5.45 & 22 & 2.69 & 12 & 3.14 \\
\hline Guerlinguetus aestuans & 7 & 1.08 & 18 & 3.27 & 5 & 0.61 & 5 & 1.31 \\
\hline $\begin{array}{c}\text { Total } \\
\end{array}$ & 68 & 10.46 & 87 & 15.82 & 66 & 8.07 & 48 & 12.55 \\
\hline Rate $=\mathrm{n}^{\circ}$ of sightings $/ 10 \mathrm{kn}$ & at. $=$ sig & & & & & & & \\
\hline
\end{tabular}

These results may even corroborate the idea that hunting, despite low levels, has an impact on the impoverishment of communities (Peres, 2000; Parry et al., 2009). It is possible to even associate this situation with the fact that most parts of protected areas in the Amazon are accessible because of its large watershed (Peres \& Lake, 2003; Antunes et al., 2016). This impact may be increased by the use of firearms, which is different from the results obtained by most studies of traditional hunting in indigenous tribes (Endo et al., 2010; Espinosa et al., 2014).

The confirmation of the presence of $2 / 3$ of the 52 expected species in the studied region indicates that the methods used in this survey of species richness are satisfactory and highlights the importance of complementary registers in inventories of mammals (Fragoso et al. 2016). In the analysis of abundance, the 
Andrade et al.: Accessibility do not explain abundance of medium and large-

sized mammals

line transects method and camera traps are essential. Moreover, these tools complement each other in the study of the groups of registered mammals, as shown in the Santos and Mendes-Oliveira (2012) research. Line transects are efficient to register diurnal fauna, especially that of Primates. However, this demands a great sampling effort for the detection, and calculation of species density (Fragoso et al. 2016). Camera traps are more efficient to register nocturnal animals with discrete habits, such as the carnivores (Silveira $e t$ al. 2003).

The protected areas studied have an important role in biological conservation, not only for those communities of mammals, but also for harboring endangered and vulnerable species of the mastofauna. The absence of Chiropotes albinasus and Mico argentatus on the right bank of the Iriri River confirms the geographical distribution proposed by Reis et al. (2010). Nevertheless, not detecting Mico emiliae in this same area is intriguing because this species was registered in the Nacional Park Serra do Pardo, located 100 $\mathrm{km}$ east of the TMES (Portella et al. 2018). The absence of some expected species in the area may be related to factors such as cryptic and nocturnal habits, naturally low population densities and behavioral changes in response to anthropic actions (Fragoso et al. 2016).

Table 3. Orders and species registered by the camera trap method in the TMES and CSIL during the period of May 2014 and May 2016.

\begin{tabular}{|c|c|c|c|c|c|c|c|c|}
\hline \multirow[b]{2}{*}{ Taxon } & \multicolumn{2}{|c|}{ TMES I (3.064h) } & \multicolumn{2}{|c|}{ TMES II (3.120h) } & \multicolumn{2}{|c|}{$\begin{array}{c}\text { CSILI } \\
(4.117 \text { h }) \\
\end{array}$} & \multicolumn{2}{|c|}{$\begin{array}{c}\text { CSILII } \\
(1.421 \text { h) }\end{array}$} \\
\hline & Reg & $\mathbf{R} / \mathbf{S E}$ & Reg & R/SE & Reg & R/SE & Reg & R/SE \\
\hline Artiodactyla & 8 & 0.063 & 28 & 0.215 & 30 & 0.175 & 1 & 0.017 \\
\hline Mazama americana & 1 & 0.008 & 13 & 0.100 & 22 & 0.128 & & \\
\hline Mazama nemorivaga & 1 & 0.008 & 7 & 0.054 & & & & \\
\hline Pecari tajacu & 5 & 0.039 & 7 & 0.054 & 5 & 0.029 & 1 & 0.017 \\
\hline Tayassu pecari & 1 & 0.008 & 1 & 0.008 & 3 & 0.017 & & \\
\hline Carnivora & 2 & 0.02 & 11 & 0.085 & 17 & 0.099 & 2 & 0.034 \\
\hline Cerdocyon thous & & & 1 & 0.008 & 1 & 0.006 & & \\
\hline Eira barbara & & & & & & & 1 & 0.017 \\
\hline Leopardus pardalis & 2 & 0.016 & 5 & 0.038 & 10 & 0.058 & 1 & 0.017 \\
\hline Leopardus wiedii & & & 1 & 0,008 & & & & \\
\hline Nasua nasua & & & & & 2 & 0.012 & & \\
\hline Panthera onca & & & 2 & 0,015 & 1 & 0.006 & & \\
\hline Procyon cancrivorus & & & & & 2 & 0.012 & & \\
\hline Puma concolor & & & 2 & 0.015 & 1 & 0.006 & & \\
\hline Cingulata & 1 & 0.01 & 2 & 0.015 & 11 & 0.064 & 2 & 0.034 \\
\hline Dasypus kappleri & & & & & 1 & 0.006 & 2 & 0.034 \\
\hline Dasypus novemcinctus & 1 & 0.008 & 2 & 0.015 & 9 & 0.052 & & \\
\hline Priodontes maximus & & & & & 1 & 0.006 & & \\
\hline Perissodactyla & 29 & 0.227 & 12 & 0.092 & 9 & 0.052 & & \\
\hline Tapirus terrestris & 29 & 0.227 & 12 & 0.092 & 9 & 0.052 & & \\
\hline Pilosa & & & & & 1 & 0.006 & & \\
\hline Myrmecophaga tridactyla & & & & & 1 & 0.006 & & \\
\hline Rodentia & 16 & 0.13 & 135 & 1.038 & 36 & 0.210 & 6 & 0.101 \\
\hline Cuniculus paca & 3 & 0.023 & 37 & 0.285 & 23 & 0.134 & & \\
\hline Dasyprocta leporina & 13 & 0.102 & 98 & 0.754 & 13 & 0.076 & 6 & 0.101 \\
\hline Total & 56 & 0.439 & 188 & 1.466 & 104 & 0.606 & 11 & 0.186 \\
\hline \multicolumn{9}{|c|}{ Reg = Registers $;$ SE = Sample effort. } \\
\hline
\end{tabular}

The higher rate of sightings compared to other studies in the region may be associated with the fact that this is an area of permanent preservation, which was also observed in similar studies (Ravetta 2001; 
Sampaio et al. 2010). Besides this, the difference observed in the Chi-Square test among the sampled transects leads us to infer that the differences in the composition of communities of an area may not be explained by the analysis of one or two factors, but by the interaction of several variables (Tardio \& Da Silveira 2015).

Terra do Meio proved to be an area with good conditions for conservation, as it can be observed in the presence of predators and large cynegetic mammals. However, the increase in hunting activities, forest exploitation and deforestation, can lead, in the short term, to a reduction in the densities of some populations and even to local extinctions.

Finally, Terra do Meio proved to be an area with good conditions for conservation. However, the increase in hunting activities, forest exploitation and deforestation, can lead, in the short term, to a reduction in the densities of some populations and even to local extinctions as reported in some studies (Fialho 2007; Travassos 2011). This also emphasizes the need to increase the monitoring of peripheral areas of units of conservation so that these units fulfill their roles in the conservation once there is a lack of efficient conservation policies in the region.

ACKNOWLEDGEMENTS. The authors thank Mr. Claudivan Zanella and Mr. Hildo Morais for their help in field trips. We would like to acknowledge Dr. Hermes Fonseca and Dr. Thiago Bernardi, for contributing to the statistical analysis, Dr. André Ravetta, for giving us instructions on how to use the program DISTANCE, and FUNAI, for providing the appropriate authorizations for our research in the indigenous area (022/AAEP/PRESS/2016). We also thank ICMBIO 48195-2, for providing the authorization to conduct our research in the TMES and the Program of Support for Qualified Production - PAPQ / UFPA (process 23073.009525/2017-17).

\section{LITERATURE CITED}

Alvares, C. A., Stape, J. L., Sentelhas, P. C., de Moraes, G., Leonardo, J., Sparovek, G. (2013) Köppen's climate classification map for Brazil. Meteorologische Zeitschrift, 22, 711-728.

Alvard, T. (1993) "Testing the "Ecologically Noble Savage" Hypothesis: Interespecific Prey Choices by Piro Hunters in Amazonian Peru". Human Ecology, 4, 335-87.

Andrade, R. P. (2006) Levantamento populacional de mamíferos terrestres e arborícolas não voadores de médio e grande porte no sul do município de Uruará. Trabalho de Conclusão de Curso. Faculda de de Ciências Biológicas. Universidade Federal do Pará, Belém, Pará, 18 pp.

Antunes, A. P., Fewster, R. M., Venticinque, E. M., Peres, C. A., Levi, T., Rohe, F., Shepard, G. H. (2016) Empty forest or empty rivers? A century of commercial hunting in Amazonia. Science Advances, 2, e1600936.

Azevedo, F. C. C., Conforti, V. C. (2008) Decline of peccaries in a protected subtropical forest of Brazil: toward conservation issues. Mammalia, 72, 82-88.

Beisiegel, B. M. (2009) Inventário e diagnóstico da mastofauna terrestre e semi-aquática de médio e grande portes da Estação Ecológica da Terra do Meio e do Parque Nacional da Serra do Pardo, PA. Centro Nacional de Pesquisas e Conservação dos Mamíferos Carnívoros/Instituto Chico Mendes de Conservação da Biodiversidade, Atibaia, São Paulo, 64 pp.

Benchimol, M., Peres, C. A. (2015) Predicting local extinctions of Amazonian vertebrates in forest islands created by a mega dam. Biological Conservation, 187, 61-72.

Benítez-López, A., Alkemade, R., Schipper, A. M., Ingram, D. J., Verweij, P. A., Eikelboom, J. A. J., Huijbregts, M. A. J. (2017) The impact of hunting on tropical mammal and bird populations. Science, 356, 180-183. 
Andrade et al.: Accessibility do not explain abundance of medium and large-

sized mammals

Brown, K. S. J., Brown, G. G. (1992) Habitat alteration and species loss in Brazilian forests, pp. 119-142. In: Whitmore, T. C., Sayer, J. A. (Eds.). Tropical deforestation and species extinctions. Chapman \& Hall. Books, London.

Burnham, K. P., Anderson, D. R., Laake, J. L. (1980) Estimation of density from line transect sampling of biological populations. Wildlife Monographs, 72, 1-202.

Constantino, P. (2016) Deforestation and hunting effects on wildlife across Amazonian indigenous lands. Ecology and Society, 21, 3.

Costa, W. O. (2006) Levantamento populacional de mamíferos terrestres e arborícolas não voadores de médio e grande porte na margem esquerda do Rio Iriri no município de Altamira. Trabalho de Conclusão de Curso. Faculdade de Ciências Biológicas. Universidade Federal do Pará, Belém, Pará, $20 \mathrm{pp}$.

Costa-Pereira, R., Roque, F. O., Constantino, P. A. L., Sabino, J., Uehara-Prado, M. (2013) Monitoramento in situ da biodiversidade: Proposta para um sistema brasileiro de monitoramento da biodiversidade. ICMBio. Brasilia, Distrito Federal, 61 pp.

Cullen Júnior, L., Valladares-Pádua, C., Bodmer, R. E. (2000) Effects of hunting in habitat fragments of the Atlantic forest. Biological Conservation, 95, 49-65.

De Andrade Melo, É. R., Gadelha, J. R., da Silva, M. D. N. D., da Silva Júnior, A. P., Pontes, A. R. M. (2015) Diversity, abundance and the impact of hunting on large mammals in two contrasting forest sites in northern amazon. Wildlife Biology, 21, 234-245.

De Souza-Mazurek, R. R., Pedrinho, T., Feliciano, X., Hilário, W., Gerôncio, S., Marcelo, E. (2000) Subsistence hunting among the Waimiri Atroari indians in central Amazonia, Brazil. Biodiversity \& Conservation, 9, 579-596.

Doblas, J. (2015) Rotas do saque: violações e ameaças à integridade territorial da Terra do Meio. ISAInstituto socioambiental, São Paulo, São Paulo, 48 pp.

Eisenberg, J. F., Redford, K. H. (1999) Mammals of the Neotropics, Volume 3. The Central Neotropics: Ecuador, Peru, Bolivia, Brazil, 609 pp.

Emmons, L. H., Feer, F. (1997) Neotropical Rainforest mammals. A Field Guide, 2nd edn. The University Chicago Press, Chicago, USA, 330 pp.

Endo, W., Peres, C. A., Salas, E., Mori, S., Sanchez-Vega, J. L., Shepard, G. H., Yu, D. W. (2010) Game vertebrate densities in hunted and nonhunted forest sites in Manu National Park, Peru. Biotropica, 42, 251-261.

Espinosa, S., Branch, L. C., Cueva, R. (2014) Road development and the geography of hunting by an Amazonian indigenous group: consequences for wildlife conservation. PLoS ONE, 9, e114916.

Fialho, M. S. (2007) Riqueza e abundância da fauna de médio e grande porte em três modelos de áreas protegidas no sul do Brasil. Tese de Doutorado em Ecologia, Universidade Estadual de Campinas, Campinas, São Paulo, 118 pp.

Fragoso J. (1998) Home range and movement patterns of white-lipped peccary, Tayassu pecari herds in the northern Brazilian Amazon. Biotropica, 30, 458-469.

Fragoso, J. M. V., Silvius, K. M., Villa-Lobos, M. (2000) Wildlife management at the Rio das Mortes, Xavante Reserve, MT, Brazil: integrating indigenous culture and scientific method for conservation. World wildlife Fund-Brazil, Brasilia, Brazil, 68 pp.

Fragoso, J. M. V., Levi T., Oliveira L. F. B., Luzar, J. B., Overman, H., Read, J. M. (2016) Line Transect Surveys Underdetect Terrestrial Mammals: Implications for the Sustainability of Subsistence Hunting. PLoS ONE, 11, e0152659.

Gill, J. A., Sutherland, W. J., Watkinson, A. R. (1996) A method to quantify the effects of human disturbance on animal populations. Journal of Applied Ecology, 33, 786-792.

Harrison, R. D. (2011) Emptying the forest: hunting and the extirpation of wildlife from tropical nature reserves. BioScience, 61, 919-924.

Instituto Chico Mendes de Conservação da Biodiversidade (ICMBio) (2015) Conheça o plano de manejo da Estação Ecológica Terra do Meio. Instituto Chico Mendes de Conservação da Biodiversidade/Ministério do Meio Ambiente. Brasília, Distrito Federal, 298 pp. 
ISA - Instituto Socioambiental (2016) Terra Indígena Cachoeira Seca do Iriri. Available at: http://ti.socioambiental.org/pt-br/\#!/pt-br/terras-indigenas/3593 (accessed on August 2016).

IUCN - The IUCN - Red List of Threatened Species ${ }^{\text {TM }}$. Version 2016-1. (2016) Available at: http://www.iucnredlist.org (accessed on August 2016).

Laurance, W. F., Croes, B. M., Tchignoumba, L., Lahm, S. A., Alonso, A., Lee, M. E., Campbell, P., Ondzeano, C. (2006) Impacts of roads and hunting on central-African rainforest mammals. Conservation Biology, 20, 1251-1261.

Laurance, W. F., Goosem, M., Laurance, S. G. W. (2009) Impacts of roads and linear clearings on tropical forests. Trends in Ecology and Evolution, 24, 659-669.

Levi, T., Shepard Jr, G. H., Ohl-Schacherer, J., Peres, C. A., Yu, D. W. (2009) Modelling the long-term sustainability of indigenous hunting in Manu National Park, Peru: landscape-scale management implications for Amazonia. Journal of Applied Ecology, 46, 804-814.

Luna, R. B. de, Reyes, A. F. A., de Lucena, L. R. R., Pontes, A. R. M. (2017) Terrestrial mammal assemblages in protected and human impacted areas in Northern Brazilian Amazonia. Nature Conservation, 22, 147.

Melo, E. R., Gadelha, J. R., Silva. M. N. D., Silva, Jr. A. P., Pontes, A. R. M. (2015) Diversity, abundance and the impact of hunting on large mammals in two contrasting forest sites in northern Amazon. Wildlife Biology, 21, 234-245.

Meyer, N. F. V., Esser, H. J., Moreno, R., van Langevelde, F., Lieftinga, Y., Oller, D. R., Vogels, C. B. V., Carver, A. D., Nielsend, C. K., Jansen, P. A. (2015) An assessment of the terrestrial mammal communities in forests of Central Panama, using camera-trap surveys. Journal of Nature Conservation, 26, 28-35.

Naranjo, E., Bodmer, R. (2007) Source-sink systems and conservation of hunted ungulates in the Lacandon Forest, Mexico. Biological Conservation, 138, 412-420.

Ministério do Meio Ambiente (MMA) (2007) Cadastro Nacional de Unidades de Conservação. Available at: http://www.mma.gov.br/areas-protegidas/cadastro-nacional-de-ucs (accessed on August 2016).

Parry, L., Barlow, J., Peres, C. A. (2009) Allocation of hunting effort by Amazonian smallholders: implications for conserving wildlife in mixed-use landscapes. Biological Conservation, 142, $1777-$ 1786.

Peres, C. A. (2000) Effects of subsistence hunting on vertebrate community structure in Amazonian forests. Conservation Biology, 14, 240-253.

Peres, C. A. (2001) Synergistic effects of subsistence hunting and habitat fragmentation on Amazonian forest vertebrates. Conservation Biology, 15, 1490-1505.

Peres, C. A., Cunha A. A. (2011) Manual para censo e monitoramento de vertebrados de médio e grande porte por transecção linear em florestas tropicais. Wildlife Technical Series, Wildlife Conservation Society, Brazil, $32 \mathrm{pp}$.

Peres, C. A., Lake, I. R. (2003) Extent of nontimber resource extraction in tropical forests: accessibility to game vertebrates by hunters in the Amazon basin. Conservation Biology, 17, 521-535.

Pimentel, D., Stachow, U., Takacs, D. A., Brubaker, H. W., Dumas, A. R., Meaney, J. J., O'Neil, J. A. S., Onsi, D. E., Corzilius, D. B. (1992) Conserving biological diversity in agricultural/forestry systems. BioScience, 42, 354-362.

Portella, R. A., Mourthe, I., Saccardi, V., Hernández-Ruz, E. J. (2018) Eastern extension of the geographic range of Mico emiliae. Acta Amazonica, 48, 259-262.

Ravetta, A. L. (2001) O coatá-de-testa-branca (Ateles marginatus) do baixo Rio Tapajós, Pará: distribuição, abundância e conservação. Dissertação de Mestrado, Universidade Federal do Pará, Programa de Pós-Graduação em Zoologia/ Museu Paraense Emílio Goeldi, Belém, Pará, 66 pp.

R Core Team (2018) R: A language and environment for statistical computing. R Foundation for Statistical Computing, Vienna, Austria. https://www.R-project.org/.

Redford, K. H. (1992) The empty forest. Bioscience, 42, 414-422.

Reis, N. L., Perachi, A. L., Fregonezi, M. N., Rossaneis, B. K. (2010) Mamíferos do brasil: guia de identificação. Technical books, Rio de Janeiro, 560 pp. 
Andrade et al.: Accessibility do not explain abundance of medium and large-

sized mammals

Sampaio, R., Lima, A. P., Magnusson, W. E., Peres, C. A. (2010) Long-term persistence of midsized to large-bodied mammals in Amazonian landscapes under varying contexts of forest cover. Biodiversity and Conservation, 19, 2421-2439.

Santos, F. S., Mendes-Oliveira, A. C. (2012) Diversity of medium and large sized mammals in the Urucu basin, Amazonas, Brazil. Biota Neotropica, 12, 282-291.

Silveira, L., Jácomo, A. T. A., Diniz-Filho, J. A. F. (2003) Camera trap, line transect census and track surveys: a comparative evaluation. Biological Conservation, 114, 351-355.

Sirén, A.H., Cárdenas, J. C., Machoa, J. D. (2006) The relation between income and hunting in tropical forests: an economic experiment in the field. Ecology and Society, 11, 44.

Souza, L. L., Carvalho, M. P., Cruz Neto, E. H., Costa, M. P. (2002) Análise comparativa da diversidade e biogeografia dos mamíferos terrestres e arborícolas na área de influência da UHE de Belo Monte no Pará, In: Resumos do XXIV ${ }^{o}$ Congresso Brasileiro de Zoologia, Editora e Gráfica Berger, v. único, Itajaí, Santa Catarina, p. 537.

Tardio, B. M. R., Da Silveira, R. (2015) The role of forest structure and human occupation in structuring mammal assemblages in oligotrophic ecosystems of Central Amazonia. Austral Ecology, 40, 318330.

Travassos, L. (2011) Impacto da sobrecaça em populações de mamíferos e suas interações ecológicas nas florestas neotropicais. Oecologia Australis, 15, 380-411.

Wilson D. E., Reeder, D. M. (2005) Mammal Species of the World. A Taxonomic and Geographic Reference (3rd), Johns Hopkins University Press (available at Johns Hopkins University Press, 1800-537-5487 or (410) 516-6900, or at http://www.press.jhu.edu).

Zar, J. H. (1974) Biostatistical analysis. Englewood Cliffs, NJ: Prentice-HaIl, 620 pp. 